\title{
Cows' milk proteins cause similar Th1- and Th2-like immune response in diabetic and healthy children
}

\author{
M. G. E. Karlsson, J. Garcia, J. Ludvigsson \\ Department of Health and Environment, Clinical Research Center, Division of Pediatrics, Faculty of Health Sciences, \\ Linköping University, Linköping, Sweden
}

\section{Abstract}

Aims/hypothesis. Cows' milk proteins have been proposed to play a part in the pathogenesis of Type I (insulin-dependent) diabetes mellitus but both epidemiological and immunological studies have given conflicting results. Thus we aimed to study the immunological response to cows' milk proteins among diabetic and healthy children, focusing on the balance of Th1- and Th2-like lymphocytes.

Methods. Peripheral blood mononuclear cells from 30 Type I diabetic children (4 to 18 years old) were examined and compared with peripheral blood mononuclear cells from 18 healthy age-matched control children ( 7 to 15 years old). Expression of IFN- $\gamma$ and IL- 4 mRNA were detected by realtime RT-PCR and as protein by ELISA after stimulation with BSA, the ABBOS-peptide (a.a. 152-169) and $\beta$-lactoglobulin $(\beta \mathrm{LG})$ from cows' milk and ovalbumin from hens' egg. Phytohaemagglutinin and keyhole limpet haemocyanin were used as positive and negative controls, respectively.
Results. Bovine serum albumin caused a weak Th2like response in Type I diabetic children, whereas BSA antibodies decreased with age only among healthy children. Otherwise, cows' milk proteins (BSA, $\mathrm{ABBOS}$ and $\beta \mathrm{LG}$ ) caused increased expression for IFN- $\gamma$ and IL-4 mRNA in diabetic and healthy children. $\beta \mathrm{LG}$ caused the strongest immunological response, which decreased with age only among diabetic children. However, ovalbumin from egg caused a similar activation of the immune system and the immune response was similar in both diabetic and healthy children.

Conclusion/interpretation. Proteins from cows' milk caused an equal Th1- and Th2-like immune response in diabetic and healthy children. Thus, our results do not support the hypothesis that cows' milk antigens are important for the immune process associated with Type I diabetes. [Diabetologia (2001) 44: 1140-1147]

Keywords Th-lymphocytes, IFN- $\gamma$, IL-4, bovine serum albumin, ABBOS, $\beta$-lactoglobulin, real-time RT-PCR.
Early exposure to cows' milk has been suggested to trigger an immune reaction which slowly results in is-

\footnotetext{
Received: 6 February 2001 and in revised form: 14 May 2001

Corresponding author: Dr Maria Karlsson, Clinical Research Center, Division of Pediatrics, Faculty of Health Sciences, S-581 85 Linköping, Sweden, E-mail: Maria.Karlsson@ kfc.liu.se

Abbreviations: $\beta \mathrm{LG}, \beta$-lactoglobulin; BSA, bovine serum albumin; KLH, keyhole limpet haemocyanin; IA, insulin antibodies; IFN, interferon; IL, interleukin; OVA, ovalbumin; PBMC, peripheral blood mononuclear cells; PHA, phytohaemagglutinin; RNA, ribosome ribonucleic acid; Th, T-helper
}

let-cell destruction [1]. A diet free from cows' milk early in life has been shown to prevent diabetes [2]. Breast feeding and delayed exposure to cows' milk has been correlated to reduced incidence of Type I diabetes in humans $[3,4]$. It has therefore been suggested that avoiding dietary cows' milk protein early in life could protect animals and genetically susceptible children from Type I (insulin-dependent) diabetes mellitus $[5,6]$.

Humoral immune response and also enhanced cellular immunity has been found against different cows' milk proteins, such as bovine serum albumin [7], $\beta$ lactoglobulin $(\beta \mathrm{LG})[8-10]$ and $\beta$-casein $[11,12]$. 
The ABBOS-peptide (pre-BSA position 152-169), has been suggested to evoke abnormal immunity in diabetes-prone hosts [7]. Antibodies to the ABBOSpeptide has been proposed to react with the beta-cell protein, p69 [7]. Systemic immunisation of young NOD mice with the ABBOS-peptide might reduce the incidence of diabetes [13].

Evidence for an enhanced proliferative cellular immunity against the ABBOS-peptide has been found in children with recent onset Type I diabetes [14]. Thelper-lymphocytes (Th), have been divided into Th1- and Th2-lymphocytes based upon their different pattern of cytokine production [15]. Interferon- $\gamma$ (IFN- $\gamma$ ), tumour necrosis factor (TNF) and Interleukin-2 (IL-2) produced by Th1-like lymphocytes are thought to contribute to cell-mediated immunity, whereas humoral immunity has been suggested to be related to Th2-like lymphocytes producing cytokines like IL-4, IL-5, IL-10 and IL-13 [15]. The ABBOSpeptide can cause activation of Th1-like and Th2-like lymphocytes in diabetic and healthy children [16], as well as in high-risk first-degree relatives of Type I diabetic patients [17]. The response to ABBOS showed no Th1-like dominance in contrast to the response to a specific epitope of $\operatorname{GAD}_{65}$ (a. a. 247-279) $[18,19]$.

As earlier studies have shown an ambiguous role of cows' milk for the pathogenesis of Type I diabetes, we have used real-time RT-PCR to estimate the immunological response to cows' milk proteins among diabetic and healthy children, with a focus on the balance of Th1- and Th2-like lymphocytes. With this semi-quantitative technique we have investigated whether cows' milk proteins have a specific effect or whether other nutritional proteins can cause a similar immune response. Ovalbumin from hen's egg has been included as a control antigen, since this is one of the most abundant dietary proteins consumed after early infancy with structural relation to bovine serum albumin.

\section{Subjects and methods}

Peptides and antigens. Bovine serum albumin (minimum purification $98 \%$, recommended for cell cultures by Sigma, Stockholm, Sweden), $\beta$-lactoglubulin ( $\beta$ LG) (approximately $90 \%$ purity, Sigma), the synthetic milk-derived bovine serum albumin-peptide ABBOS, a.a. 152-169 (FKADEKKFWGKYLYEIAR) [14] (Dept of Medical and Physiological Chemistry, University of Uppsala, Sweden), ovalbumin (OVA) (minimum purification $99 \%$, Sigma), keyhole limpet haemocyanin (KLH) (Calbiochem, Lab Kemi, Stockholm, Sweden) and phytohaemagglutinin (PHA) (Sigma) were included.

Mononuclear cells from diabetic children and from healthy control children matched for age. Peripheral blood mononuclear cells (PBMC) were isolated by Ficoll Paque density gradient centrifugation (Pharmacia, Biotech, Sollentuna, Sweden) from sodium heparinised venous blood samples, obtained from 30 children (15 girls and 15 boys between $4-18$ years) with diag- nosed Type I diabetes. Samples were collected from ten patients shortly after diagnosis (4 days- 2 months), from ten patients within 3 to 12 months and from ten patients at 13 to 42 months after the onset of initial insulin therapy. Out of 29 children with Type I diabetes 28 had the diabetes-associated HLA-types DR3 and/or DR4, and DQ0301-0302 and/or DQ0501-0201. Peripheral blood mononuclear cells were also collected from 18 age-matched healthy children ( 9 girls and 9 boys between $7-15$ years). The healthy control children did not have diabetes nor any other autoimmune disease themselves or among first-degree relatives. Blood samples from children with Type I diabetes were taken when they visited the diabetes office and blood samples from healthy children were taken at school, when possible during the morning hours to avoid time differences. As blood samples from diabetic and healthy children were taken at different occasions, PBMC were cryo-preserved in nitrogen until stimulation. We have found that reduction of activity caused by freezing before later in vitro stimulation can be compensated for by increased amplification using the RT-PCR technique [18].

Peripheral blood mononuclear cells stimulated with dietary proteins. Frozen mononuclear cells were thawed, directly from $-196{ }^{\circ} \mathrm{C}$ to $+37{ }^{\circ} \mathrm{C}$, in a water-bath while adding RPMI 1640 supplemented with $10 \% \mathrm{FCS}$, and $1 \cdot 10^{6}$ PBMC were diluted in $500 \mu \mathrm{l}$ AIM V research grade (Gibco, Täby, Sweden) supplemented with $2 \mathrm{mmol} / \mathrm{l} \mathrm{L}$-glutamine, $50 \mu \mathrm{g} / \mathrm{l}$ streptomycin sulphate, $10 \mu \mathrm{g} / \mathrm{l}$ gentamicin sulphate and $2 \cdot 10^{-5} \mathrm{~mol} / \mathrm{l} 2$-mercaptoethanol (Sigma). PBMC $\left(1 \cdot 10^{6}\right)$ were stimulated with the ABBOS-peptide, BSA, $\beta$-lactoglobulin, ovalbumin, PHA or $\mathrm{KLH}$ at a concentration of $5 \mu \mathrm{g} / \mathrm{ml}$ [16] for $48 \mathrm{~h}$ at $37^{\circ} \mathrm{C}$, in $5 \% \mathrm{CO}_{2}$ to further analyse the expression of cytokine-specific mRNA. PBMC $\left(1 \cdot 10^{6}\right)$ were stimulated with the ABBOSpeptide, BSA, $\beta$-lactoglobulin or with ovalbumin at a concentration of $50 \mu \mathrm{g} / \mathrm{ml}$ or with PHA or KLH at a concentration of $5 \mu \mathrm{g} / \mathrm{ml}$, for $96 \mathrm{~h}$ at $37{ }^{\circ} \mathrm{C}$, in $5 \% \mathrm{CO}_{2}$, to further analyse cytokines in the cell supernatant. PBMC, from each individual, incubated without antigen but otherwise under the same conditions, were used as a calibrator to determine the spontaneous expression of mRNA and secretion of IFN- $\gamma$ and IL-4. In samples with limited number of cells, the order of priority for stimulation with antigens was ABBOS, BSA, $\beta$ LG, OVA, PHA and, finally $\mathrm{KLH}$.

RNA isolation and $c D N A$ synthesis. Total RNA was isolated from PBMC with RNeasy 96 (Quiagen, KEBO, Spånga, Sweden) as recommended by the supplier. Total RNA was quantified by OD at $260 \mathrm{~nm}$. Using equal amounts of total RNA (7 $\mathrm{ng} / \mu \mathrm{l})$ from PBMC, stimulated under various conditions, mRNA was primed with random hexamers and complimentary DNA (cDNA) was synthesised from the mRNA by TaqMan reverse transcription with MultiScribe reverse transcriptase (Perkin Elmer, Stockholm, Sweden), according to the manufacturer's description. The final cDNA product was stored at $-20{ }^{\circ} \mathrm{C}$ for subsequent cDNA amplification by polymerase chain reaction.

Real-time polymerase chain reaction (PCR). PCR reaction mixture (final volume $25 \mu \mathrm{l}$ ) contained TaqMan cytokine gene expression reagents (Perkin Elmer) with cytokine specific target primers and probe (IFN- $\gamma$; 4308250S or IL-4; 4308243S, FAM dye layer) and endogenous reference primers and probe (rRNA, VIC dye layer) in MicroAmp Optical 96-well reaction plate with optical caps. The reaction mixture was amplified with ABI Prism 7700 Sequence Detector (Perkin Elmer) for 40 cycles with an annealing temperature of $60{ }^{\circ} \mathrm{C}$ for IL-4 and IFN- $\gamma$. The FAM dye layer yields the results for quantification 
of the cytokine target mRNA while the VIC dye layer yields the results for quantification of the $18 \mathrm{~S}$ ribosomal RNA endogenous control. The passive reference contains the dye ROX in order to normalise for non-PCR-related fluctuations in fluorescence signal. In all experiments, controls without template as well as control RNA (Perkin Elmer) were included.

Calculation of relative quantification values. The relative quantification values for the cytokine gene expression assays were calculated from the accurate $\mathrm{C}_{\mathrm{T}}$, according to the manufacturer's description (protocol P/N 4304671, Perkin Elmer). The accurate $\mathrm{C}_{\mathrm{T}}$ represents the PCR cycle at which an increase in reporter fluorescence above a baseline signal can first be detected, obtained from both dye layers in the assay. $\mathrm{C}_{\mathrm{T}}$ value for rRNA (VIC) was substracted from the specific cytokine $\mathrm{C}_{\mathrm{T}}$ value (FAM for IFN- $\gamma$ and IL-4) to calculate $\Delta-\mathrm{C}_{\mathrm{T}}$ for the calibrator and samples in each cytokine gene expression assay. $\Delta-\mathrm{C}_{\mathrm{T}}$ values for duplicate wells of the calibrator sample for each cytokine were averaged. The average delta (calibrator) value was subtracted from the $\Delta-\mathrm{C}_{\mathrm{T}}$ values of samples to calculate their $\Delta \Delta-\mathrm{C}_{\mathrm{T}}$ (sample) value. The $\Delta \Delta-\mathrm{C}_{\mathrm{T}}$ value for duplicate wells of each cytokine sample was averaged. This operation normalises the number of target mRNA molecules to the number of rRNA molecules. Relative quantification values were obtained after calculating the 2 -average $\Delta \Delta-\mathrm{C}_{\mathrm{T}}$.

Enzyme linked immuno sorbent assay. IFN- $\gamma$ and IL-4 were measured, in cell supernatants from lymphocytes stimulated in vitro, by ELISA in microtitre wells (Costar 3690, Life Technologies, Stockholm, Sweden) coated with $2 \mu \mathrm{g} / \mathrm{ml}$ monoclonal mouse anti-human antibody (clone 2571811, R\&D Systems, Abingdon, UK) in coating-buffer (CLB, Amsterdam, Netherlands) overnight at room temperature (RT). Wells were blocked with $2 \%$ milk in PBS for $1 \mathrm{~h}$ at RT. Cell supernatants and standard (recombinant human IFN- $\gamma$, R\&D Systems) were applied in duplicates and incubated for $1 \mathrm{~h}$ at room temperature. IFN- $\gamma$ was captured by $0.20 \mu \mathrm{g} / \mathrm{ml}$ goat anti-human biotinylated polyclonal antibody ( $R \& D$ Systems) diluted in high performance ELISA-dilution buffer (CLB) for $1 \mathrm{~h}$ at RT and further incubated for $30 \mathrm{~min}$ at RT with horseradish peroxidase conjugated to poly-streptavidin $(0.1 \mu \mathrm{mol} / \mathrm{l}, \mathrm{CLB})$ which bind on the biotinylated side of the IFN- $\gamma$ sandwich. A coloured product was formed in proportion to the amount of IFN- $\gamma$, with a sensitivity of $12 \mathrm{pg} / \mathrm{ml}$ after incubation with 3,3',5,5'-tetramethylbenzidine (TMB) liquid substrate (Sigma-Aldrich) for $30 \mathrm{~min}$ in the dark and thereafter with $1.8 \mathrm{~mol} / \mathrm{l} \mathrm{H}_{2} \mathrm{SO}_{4}$ to stop the reaction. IL-4 was also measured by ELISA according to the same protocol for detecting IFN- $\gamma$, except from coating the wells with $4 \mu \mathrm{g} / \mathrm{ml}$ monoclonal mouse anti-human antibody (clone 3010.211, R\&D Systems) and detected with $0.5 \mu \mathrm{g} / \mathrm{ml}$ biotinylated polyclonal goat anti-human antibody specific for IL-4 (R\&D Systems) with a sensitivity of $3 \mathrm{pg} / \mathrm{ml}$. Antigen-induced cytokine response was presented as $\mathrm{pg} / \mathrm{ml}$ after subtracting spontaneous secreted cytokine from PBMC incubated without antigen, but otherwise cultured under the same conditions.

IgG antibodies to BSA. BSA-antibodies were measured by ELISA [17]. Microtitre wells (Costar M3590, Life Technologies) were coated with BSA (Grade V; Sigma). Wells were blocked with $2 \%$ gelatin from coldwater fish and $0.5 \%$ Tween20. Serum samples diluted 1:100 were studied in duplicate. Mouse anti-human IgG (BioZac Mo6014, Järfälla, Sweden) was incubated, followed by incubation with rabbit antimouse-ALP (Sigma A4312, Sweden) and the substrate (pNNP). The reaction was stopped with $3 \mathrm{~mol} / \mathrm{l} \mathrm{NaOH}$. Absorbance was measured at $405 \mathrm{~nm}$ wavelength. Intra-assay and inter-assay coefficients of variation for $\mathrm{IgG}$ antibodies were
$11.2 \%$ and $13.9 \%$. Occurrence of IgG within the samples was calculated out of a standard curve which was prepared from serum with high binding to BSA.

C-peptide. C-peptide was determined with an adapted radioimmunoassay (RIA) technique based on the original [20]. The detection limit for the assay is $0.03 \mathrm{nmol} / \mathrm{l}$ and the reference value among fasting healthy children and adolescents is 0.18 to $0.63 \mathrm{nmol} / 1$.

Insulin antibodies (IA). IA was detected with a radioligand competition assay according to others [21]. Insulin in the sample was removed by a acidification-and charcoal-extraction. Serum was incubated in duplicate with bovine ${ }^{125} \mathrm{I}$-insulin and ${ }^{125} \mathrm{I}$-insulin with an excess of unlabelled insulin. After incubation, free and antibody-bound ${ }^{125} \mathrm{I}$-insulin was separated with precipitation with polyethylene-glycol (PEG). A positive control (pool of sera from three IAA positive patients) and a negative control (with undetectable IAA) was included in each assay. Results were calculated as the difference between incubation with ${ }^{125} \mathrm{I}$-insulin and incubation with ${ }^{125} \mathrm{I}$-insulin and excess of unlabelled antigen. Cut-off was set at $\mathrm{M}+2 \mathrm{SD}$ for healthy control children, $99 \mathrm{nU} / \mathrm{ml}$.

Statistics. As the expression and secretion of IFN- $\gamma$ and IL-4 was not normally distributed (even after logarithmic transformation), two groups were compared with Mann-Whitney U test while three or more groups were compared with Kruskal Wallis test for unpaired observations. Spearmans rank correlation was used when comparing two non-parametric variables. A probability of less than $5 \%$ was considered to be statistically significant, whereas a $p$-value of $10 \%$ or less was regarded as a tendency. Calculations were carried out with a statistical package, StatView 5.0.1 for Macintosh (Abacus Concepts Inc, Berkeley, Calif., USA). All data are presented as medians.

Ethics. This study was approved by the Research Ethics Committee of the Faculty of Health Sciences, Linköping University. All parents or responsible guardians, on behalf of the children who participated in the study, gave their informed consent.

\section{Results}

Antigen concentration. In the initial experiments the antigens were diluted in tissue culture medium in different concentrations; $500 \mu \mathrm{g} / \mathrm{ml}, 250 \mu \mathrm{g} / \mathrm{ml}, 100 \mu \mathrm{g} /$ $\mathrm{ml}, 50 \mu \mathrm{g} / \mathrm{ml}, 25 \mu \mathrm{g} / \mathrm{ml}$ and $5 \mu \mathrm{g} / \mathrm{ml}$. Each dilution of antigen was tested by stimulating PBMC for $96 \mathrm{~h}$, after which IFN- $\gamma$ and IL-4 were detected by ELISA. An optimal concentration for all antigens was found to be $50 \mu \mathrm{g} / \mathrm{ml}$ for detection of IFN- $\gamma$ and IL-4, which was consequently used throughout the study.

Viability. The viability for all peripheral blood mononuclear cells from healthy and diabetic children was found to be approximately $90 \%$ or more for each cohort.

Immune response to $\mathrm{PHA}$ and $K L H$. Phytohaemagglutinin caused increased expression for IFN- $\gamma$ and IL-4 mRNA $(r=0.65, p=0.002)$. Increased IFN- $\gamma$ mRNA expression from PHA tended to correlate 
Table 1. Expression and secretion of IFN- $\gamma$ and expression of IL-4

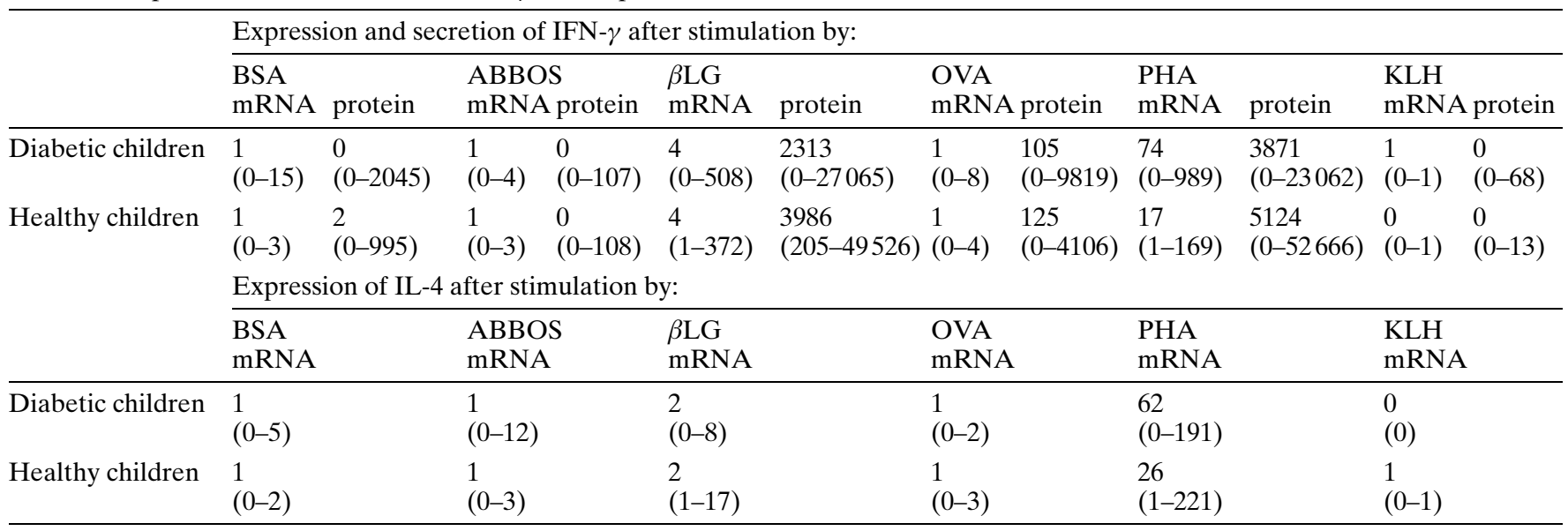

Expression of IFN- $\gamma$ and IL-4 mRNA, from stimulation with antigens after subtraction of spontaneous expressed mRNA is calculated as the relative amount of expressed cytokine in relation to rRNA. Secretion of antigen-induced IFN- $\gamma$, after subtracting spontaneous secreted cytokine, detected at $\mathrm{pg} / \mathrm{ml}$ by ELISA and illustrated as median and extremes (within parentheses)

\section{IL-4 mRNA/ rRNA}

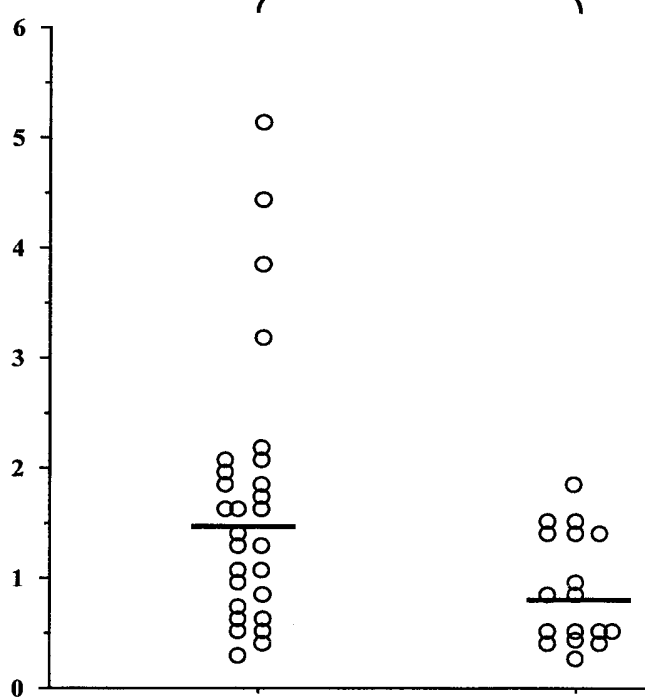

\section{Diabetic children Healthy children}

Fig.1. Slightly increased IL-4 mRNA expression by BSA in diabetic children $(n=28)$ compared with healthy children $(n=17) \quad(p=0.06)$ calculated as relative quantity of IL4 mRNA in comparison to rRNA, where horizontal lines show the median of IL-4 mRNA expression

with the secretion of IFN- $\gamma(r=0.38, p=0.08)$. Keyhole limpet haemocyanin (KLH) in general did not cause any kind of immune response to the two studied cytokines, IFN- $\gamma$ and IL-4, in populations of peripheral blood mononuclear cells from diabetic or healthy children. Furthermore, control RNA was amplified to the same extent in all reactions performed by realtime RT-PCR.
Immune response to dietary proteins. Bovine serum albumin and the ABBOS-peptide caused a weak upregulated IFN- $\gamma$ mRNA expression and the secretion of IFN- $\gamma$ was also found at a low concentration in diabetic and healthy children (Table 1). Only bovine serum albumin caused a slightly more pronounced expression of IL-4 mRNA in children with Type I diabetes than in the healthy control children $(p=0.06)$ (Fig.1). This response correlated positively to age only in the diabetic children $(r=0.47, p=0.02)$. Thus, the response to BSA and ABBOS included activation of both Th1- and Th2-like lymphocytes in diabetic and healthy children. A positive correlation between IFN- $\gamma$ and IL-4 mRNA could be seen for BSA $(r=0.34, p=0.07)$ and ABBOS $(r=0.45$, $p=0.02$ ) among diabetic children.

A pronounced expression of IFN- $\gamma$ mRNA was correlated to a distinct secretion of IFN- $\gamma$ after stimulation with $\beta$-lactoglobulin in diabetic and healthy children $(r=0.55, p=0.0004)$ (Table 1). Ovalbumin also caused an increased IFN- $\gamma$ mRNA expression which correlated with the distinct secretion of IFN- $\gamma$ in all children with or without diabetes $(r=0.47$, $p=0.02$ ) (Table 1). $\beta$-lactoglobulin caused a Th1and Th2-like immune response, similar among diabetic and healthy control children, which was stronger than the response to ABBOS, BSA and ovalbumin (Fig. 2A, B). IFN- $\gamma$ mRNA $(r=-0.48, p=0.05)$ and IL-4 mRNA $(r=-0.41, p=0.1)$ response to $\beta$-lactoglobulin tended to decrease with age only among healthy control children. Duration of diabetes did not influence the cytokine response to these dietary proteins.

Thus, dietary proteins, both bovine serum albumin, the ABBOS-peptide and $\beta$-lactoglobulin from cows' milk and ovalbumin from hens' egg caused an increased expression for IFN- $\gamma$ and IL-4 mRNA 


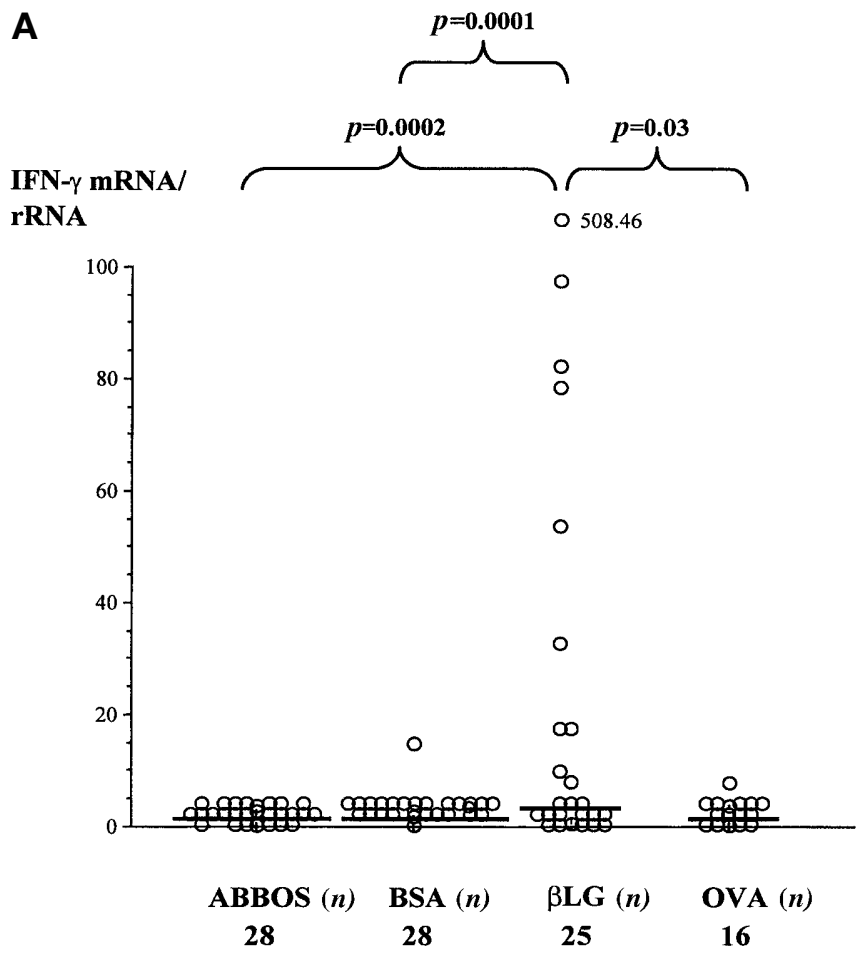

among diabetic children and healthy control children matched for age. The relative amount of expressed IFN- $\gamma$ mRNA and the product seen as protein was found to the same extent in both healthy and Type I diabetic children. Secretion of interleukin-4 was not possible to detect although IL-4 mRNA expression was seen after stimulation with either BSA or the ABBOS-peptide and to a higher extent after stimulation with $\beta$-lactoglobulin or ovalbumin.

BSA antibodies in relation to response from dietary proteins. Antibodies to bovine serum albumin were not correlated with the expression of cytokines after stimulation with dietary proteins in diabetic children, while in healthy control children, upregulated mRNA expression for IFN- $\gamma$ after stimulation with the ABBOS-peptide correlated with the production of antibodies against BSA $(r=0.46, p<0.05)$. Neither increased age of diabetic children $(r=-0.1, p=0.6)$ (Fig. 3A) nor duration of diabetes influenced the production of antibodies against BSA whereas BSA antibodies decreased with age among healthy control children $(r=-0.57, p=0.02)$ (Fig. 3B). Furthermore, antibodies against bovine serum albumin were negatively correlated to insulin antibodies at both six months duration $(r=-0.62, p=0.01)$ and at one year after diagnosis of diabetes $(r=-0.42, p=0.05)$.
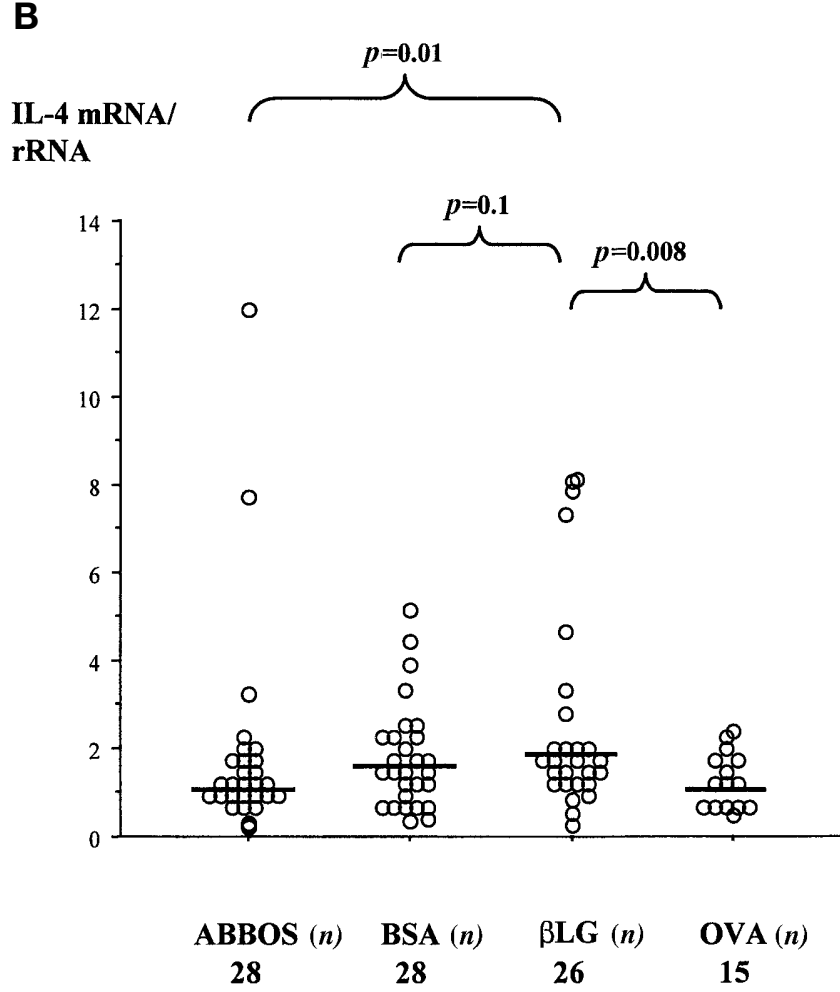

$C$-peptide and insulin antibodies in relation to response from dietary proteins. C-peptide was negatively correlated to IFN- $\gamma$ mRNA expression after ABBOS-peptide stimulation at diagnosis $(r=-0.37$, $p=0.05$ ), whereas increased IL-4 mRNA expression by BSA tended to correlate with higher C-peptide $(r=0.32, p=0.1)$. Antibodies against insulin were not associated with increased IFN- $\gamma$ nor with IL4 mRNA expression after stimulation with proteins from cows' milk or hens' egg.

\section{Discussion}

Dietary proteins have been proposed to contribute to the development of Type I diabetes. Animal models of human Type I diabetes, the NOD mice and BB rat, showed that dietary antigens and the gut immune system are key regulatory factors of disease development [22]. In general, it seems that Th1-like cells are more sensitive to tolerance induction than are Th2like cells, which in turn are more sensitive than B cells [23]. The immune balance of the gut is furthermore linked to a secretion pattern of Th2-like cytokines, in particular IL-10 and TGF- $\beta$ [24]. The gut immune system of pre-diabetic hosts could respond to certain dietary components unfavourably and in a manner that differs from the healthy gut [25].

Epidemiological studies have provided some evi-

dence for the role of cows' milk in the pathogenesis

F. 2 A, B. $\beta$-Lactoglobulin caused a stronger IFN- $\gamma \mathrm{mR}$ OVA $(p=0.03)$ (A) and IL-4 mRNA expression (B) than BSA $(p=0.1)$, ABBOS $(p=0.01)$ or OVA $(p=0.008)$ in diabetic children and was detected as relative quantity in comparison to rRNA by real-time RT-PCR. Illustrated by plots, where horizontal lines show the median of cytokine mRNA expression 
A

Diabetic children

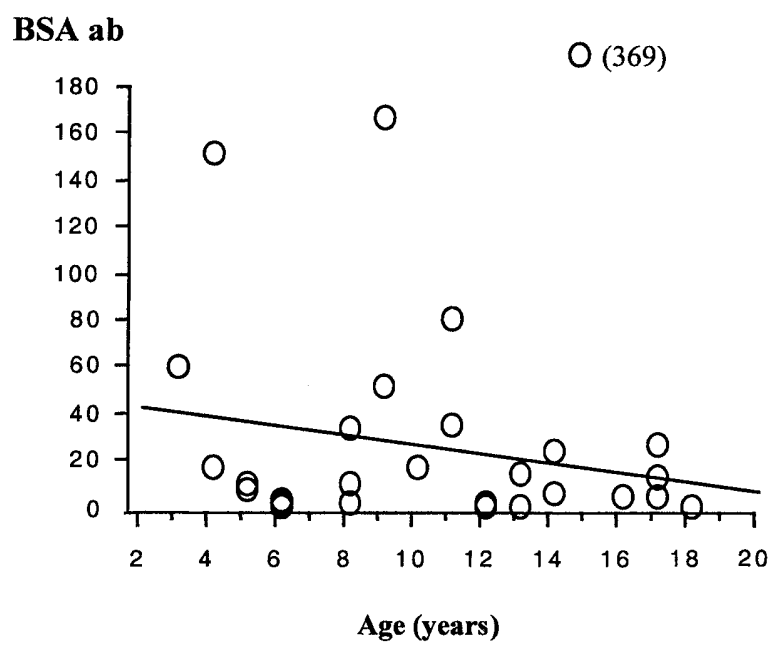

B

Healthy children

\section{BSA ab}

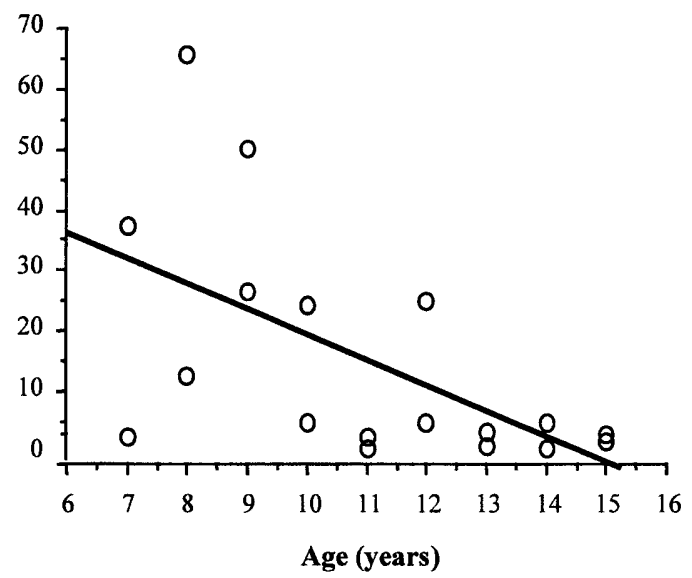

Fig. 3 A, B. Relative concentration of antibodies against BSA did not decrease with increasing age among diabetic children $(r=-0.1, p=0.6, n=30)(\mathbf{A})$ but only among healthy children $(r=-0.57, p=0.02, n=18)(\mathbf{B})$

of Type I diabetes but the results have been conflicting [26]. Antibodies against bovine serum albumin and especially the ABBOS-peptide, was shown to be capable of reacting with a beta cell-specific surface protein [7] in $100 \%$ of newly diagnosed diabetic children [27] even if this has not been confirmed by other investigators $[28,29]$. We have focused on the response of Th-like lymphocytes to components of cows' milk in children. Recently we have shown that the specific ABBOS-peptide can initiate an immune response including both activation of IFN- $\gamma$ and IL4 mRNA expression in diabetic children as well as in healthy control children [16]. Absence of cellular immunity to BSA as well as to the ABBOS-peptide in diabetic children could indicate that this antigen is of little importance in the pathogenesis of diabetes [30].
Realtime RT-PCR is a rather new technique which allows us to make a semi-quantification of the amount of expressed cytokine by observing at which cycle of the polymerase chain reaction a specific messenger RNA expression can be detected above the baseline. The technique was multiplexed, including primers and probes for the specific cytokine as well as for the internal control ribosomal RNA, to normalise for differences during cDNA synthesis. The technique seems promising since we have been able to observe an increased response to the positive control antigen phytohaemagglutinin, whereas no response was observed in the negative control antigen, keyhole limpet haemocyanin. Response to PHA included a powerful activation of IFN- $\gamma$ and IL-4 mRNA expression among diabetic and healthy children without any significant deviation to either a Th1- or Th2-like cytokine profile. Thus, a Th1-like profile may be more pronounced during the pre-diabetic phase than after the development of manifest Type I diabetes [17].

To control that expressed mRNA was translated to protein, secreted cytokine was detected by ELISA. The relative amount of expressed IFN- $\gamma$ mRNA and secreted IFN- $\gamma$ was found to the same extent in healthy and in Type I diabetic children. We failed to detect secreted IL-4 though we were able to detect expressed IL-4 mRNA. Lack of detectable amounts of secreted IL-4 can possibly be explained by the recent observation that the IL-4 receptor is widely expressed on different cell types [31]. Difficulties to detect IL-4 in cell supernatant could therefore be due to the in vitro consumption of IL-4 [31].

The ABBOS-peptide caused increased IFN- $\gamma$ and IL-4 mRNA expression in both healthy and diabetic children. Diabetic children who responded by increased expression of IFN- $\gamma$ mRNA against the ABBOS-peptide produced lower amounts of endogenous insulin than non-responding patients. This corresponds with our previous finding among newly diagnosed diabetic children [16]. BSA caused a weak upregulation of IL-4 mRNA which increased with age in diabetic children. Furthermore, BSA antibodies were found to decrease with age only among healthy children, confirming previous results where BSA antibodies are found not to decrease with duration of disease [32]. We cannot exclude that humoral immune reactivity to BSA in Type I diabetic patients might just reflect an unspecific reaction of the immune system with no additional diagnostic value for Type I diabetes [30, 33]. However, although these findings do not support a role of BSA as a diabetogenic factor these findings could indicate the basic regulatory defect in Type I diabetes [25].

Increased levels of IgA antibodies to whole cows' milk and $\beta$-lactoglobulin has been found in newly diagnosed Type I diabetic children $[34,35]$. IgA antibodies to $\beta$-lactoglobulin has been suggested as a risk determinant for Type I diabetes independent of 
the ICA concentration and introduction of cows' milk formula [36]. Furthermore, increased T-cell response to $\beta$-lactoglobulin has been found in children with newly diagnosed Type I diabetes [10]. Our results show that expression of IFN- $\gamma$ and IL-4 mRNA by $\beta$-lactoglobulin was highly increased compared to the response seen after stimulation with BSA, ABBOS or ovalbumin in diabetic and healthy children. The response to $\beta$-lactoglobulin decreased with age only among healthy children, which could indicate disturbance in oral tolerance mechanisms in Type I diabetic children [25]. The response to dietary proteins and PHA remained the same even when excluding diabetic children who were not tightly matched for age (4-6 and 16-18 years). Thus, $\beta$-lactoglobulin is able to cause a strong immune response, including increased expression of IFN- $\gamma$ and IL- 4 mRNA, but this response is not specific to diabetic children but is found in all children.

Ovalbumin with structural relation to BSA has been chosen as a relevant control antigen. Antibodies against ovalbumin have been found to the same extent in diabetic and control children [37]. Ovalbumin antibodies have also been found more frequently than antibodies against cows' milk proteins among healthy adults [38]. Our results show that diabetic children of the same age as healthy children respond to ovalbumin by increased expression for both IFN- $\gamma$ and IL4 mRNA. The response seen from this egg protein was similar to the response seen after stimulation with either bovine serum albumin or the ABBOS-peptide. We observed no immune deviation towards a Th2-like immune response by ovalbumin which has previously been shown to favour oral tolerance [39].

In conclusion, proteins from cows' milk do not seem to cause a Th1-like deviation. On the contrary, BSA caused a Th2-like deviation which rather suggest an allergic type of reaction. In addition, the hens' egg protein, ovalbumin, caused a similar response as cows' milk proteins. Finally, the response is similar in both diabetic and healthy children. Thus our results do not support the hypothesis that cows' milk antigens are important for the development of Type I diabetes.

Acknowledgements. This study has been generously supported by the Söderberg Foundation, Swedish Medical Research Council (\#K99-72X-11242-05A), Novo Nordisk Research Foundation, JDF-Wallenberg (K98-99JD-12813-01A), Medical Research Foundation of the County of Östergötland, Samaritens' Foundation, the Swedish Diabetes Foundation, the Swedish Child Diabetes Foundation and the Queen Silvia's Jubilee Foundation. The laboratory work was carried out at the Clinical Research Centre of the Faculty of Health Sciences. We gratefully acknowledge U. Ludvigsson and I. Franzén for their skillful help with taking bloodsamples from healthy schoolchildren. We also thank the staff at the pediatric clinic for their help with taking the blood samples. We thank V. Sadauskaite, S. Hellström and L. Berglert for skilful technical assistance and M. Jenmalm for establishment of cytokine ELISA assay.

\section{References}

1. Robinson BH, Dosch HM, Martin JM et al. (1993) A model for the involvement of MHC class II proteins in the development of Type I (insulin-dependent) diabetes mellitus in response to bovine serum albumin peptides. Diabetologia 36: 364-368

2. Elliott RB, Martin JM (1984) Dietary protein: a trigger of insulin-dependent diabetes in the BB rat? Diabetologia 26: 297-299

3. Borch-Johnsen K, Joner G, Mandrup-Poulsen $\mathrm{T}$ et al. (1984) Relation between breast-feeding and incidence of insulin-dependent diabetes mellitus. Lancet ii: 1083-1086

4. Virtanen SM, Räsänen L, Aro A (1991) Infant feeding in Finnish children $<7$ yr of age with newly diagnosed IDDM. Diabetes Care 14: 415-417

5. Virtanen SM, Räsänen L, Ylönen K et al. (1993) Early introduction of dairy products associated with increased risk of IDDM in Finnish children. Diabetes 42: 1786-1790

6. Åkerblom HK, Savilahti E, Saukkonen TT et al. (1993) The case for elimination of cow's milk in early infancy in the prevention of type 1 diabetes: The Finnish experience. Diabetes Metab Rev 9: 269-278

7. Karjalainen J, Martin JM, Knip M et al. (1992) A bovine albumin peptide as a possible trigger of insulin-dependent diabetes mellitus. New Eng J Med 327: 302-307

8. Dahlqvist G, Savilathi E, Landin Olsson M (1992) An increased level of antibodies to beta-lactoglobulin is a risk determinant for early-onset Type I (insulin-dependent) diabetes mellitus independent of islet cell antiboides and early introduction of cow's milk. Diabetologia 35: 980-984

9. Savilahti E, Saukkonen TT, Virtala ET, Tuomilehto J, Åkerblom HK (1993) Increased levels of cow's milk and $\beta$-lactoglobulin antibodies in young children with newly diagnosed IDDM. Diabetes Care 16: 984-989

10. Vaarala O, Klemetti P, Savilahti E, Reijonen H, Ilonen J, Åkerblom HK (1996) Cellular immune response to cow's milk $\beta$-lactoglobulin in patients with newly diagnosed IDDM. Diabetes 45: 178-182

11. Cavallo MG, Fava D, Monetini L, Barone F, Pozzilli P (1996) Cell-mediated immune response to $\beta$ casein in recent-onset insulin-dependent diabetes: implications for disease pathogenesis. Lancet 348: 926-928

12. Ellis TM, Ottendorfer E, Jodoin E et al. (1998) Cellular immune responses to $\beta$ casein: elevated in but not specific for individuals with Type I diabetes mellitus. Diabetologia 41: 731-735

13. Karges W, Hammond-McKibben D, Gaedigk R, Shibuya N, Cheung R, Dosch HM (1997) Loss of self-tolerance to ICA69 in nonobese diabetic mice. Diabetes 46: 1548-1556

14. Cheung R, Karjalainen J, Vandermeulen J, Singal DP, Dosch H-M (1994) T cells from children with IDDM are sensitized to bovine serum albumin. Scand J Immunol 40: 623-628

15. Mosmann TR, Sad S (1996) The expanding universe of Tcell subsets: Th1, Th2 and more. Immunol Today 17: 138-146

16. Karlsson MGE, Ludvigsson J (2000) The ABBOS-peptide from bovine serum albumin causes an IFN- $\gamma$ and IL4 mRNA response in lymphocytes from children with recent onset of type 1 diabetes. Diabetes Res Clin Pract 47: 199-207

17. Karlsson MGE, Sederholm Lawesson S, Ludvigsson J (2000) Th1-like dominance in high-risk first-degree relatives of Type I diabetic patients. Diabetologia 43: 742-749

18. Karlsson MGE, Ludvigsson J (1998) Determination of mRNA expression for IFN- $\gamma$ and IL-4 in lymphocytes 
from children with IDDM by RT-PCR technique. Diabetes Res Clin Pract 40: 21-30

19. Karlsson MGE, Ludvigsson J (1998) Peptide from glutamic acid decarboxylase similar to coxsackie B virus stimulates IFN- $\gamma$ mRNA expression in Th1-like lymphocytes from children with recent-onset insulin-dependent diabetes mellitus. Acta Diabetol 35: 137-144

20. Heding LG (1975) Radioimmunological determination of human C-peptide in serum. Diabetologia 11: 541-548

21. Palmer JP, Asplin CM, Clemons P et al. (1983) Insulin antibodies in insulin-dependent diabetics before insulin treatment. Science 222: 1337-1339

22. Scott FW, Cloutier HE, Kleemann R et al. (1997) Potential mechanisms by which certain foods promote or inhibit the development of spontaneous diabetes in BB rats. Diabetes 46: 589-598

23. Husby S, Mestecky J, Moldoveanu Z, Holland S, Elson CO (1994) Oral tolerance in humans: T cell but not B cell tolerance after antigen feeding. J Immunol 152: 4663-4670

24. Weiner HL (1997) Oral tolerance: immune mechanisms and treatment of autoimmune diseases. Immunol Today 18: $335-343$

25. Kolb H, Pozzilli P (1999) Cow's milk and type 1 diabetes: the gut immune system deserves attention. Immunol Today 20: $108-110$

26. Scott FW, Norris JM, Kolb H (1996) Milk and type I diabetes: examining the evidence and broadening the focus. Diabetes Care 19: 379-383

27. Karjalainen J, Saukkonen T, Savilahti E, Dosch HM (1992) Disease-associated anti-bovine serum albumin antibodies in Type I (insulin-dependent) diabetes mellitus are detected by particle concentration fluoroimmunoassay, and not by enzyme linked immunoassay. Diabetologia 35: 985-990

28. Ivarsson S-A, Månsson MUL, Jakobsson IL (1995) IgG antibodies to bovine serum albumin are not increased in children with IDDM. Diabetes 44: 1349-1350

29. Füchtenbusch M, Karges W, Standl E, Dosch HM, Ziegler AG (1997) Antibodies to bovines serum albumin (BSA) in Type I diabetes and other autoimmune disorders. Exp Clin Endocrinol Diabetes 105: 86-91

30. Atkinson MA, Bowman MA, Kao KJ et al. (1993) Lack of immune responsiveness to bovine serum albumin in insulin-dependent diabetes. N Engl J Med 329: 1853-1858
31. Bullens DMA, Kasran A, Peng X, Lorré K, Ceuppens JL (1998) Effects of anti-IL-4 receptor monoclonal antibody on in vitro T cell cytokine levels: IL-4 production by T cells from non-atopic donors. Clin Exp Immunol 113: 320-326

32. Yokota A, Yamaguchi Y, Ueda Y et al. (1990) Comparison of islet cell antibodies, islet cell surface antibodies and anti-bovine serum albumin antibodies in type 1 diabetes. Diabetes Res Clin Pract 9: 211-217

33. Lühder F, Schlosser M, Michaelis D, Ziegler B, Kohnert KD, Ziegler M (1994) No association between anti-bovine serum albumin antibodies and islet cell reactive antibodies in newly diagnosed type 1 diabetic patients. Diabetes Res Clin Pract 26: 35-41

34. Savilahti E, Åkerblom HK, Tainio VM, Koskimies S (1988) Children with newly diagnosed insulin dependent diabetes mellitus have increased levels of cow's milk antibodies. Diabetes Res 7: 137-140

35. Saukkonen T, Savilahti E, Landin-Olsson M, Dahlqvist G (1995) IgA bovine serum albumin antibodies are increased in newly diagnosed patients with insulin-dependent diabetes mellitus, but the increase is not an independent risk for diabetes. Acta Pediatr 84: 1258-1261

36. Dahlqvist G, Savilathi E, Landin Olsson M (1992) An increased level of antibodies to $\beta$-lactoglobulin is a risk determinant for early-onset Type I (insulin-dependent) diabetes mellitus independent of islet cell antibodies and early introduction of cow's milk. Diabetologia 35: 980-984

37. Saukkonen T, Savilahti E, Vaarala O, Virtala ET, Tuomilehto J, Åkerblom HK (1994) Children with newly diagnosed IDDM have increased levels of antibodies to bovine serum albumin but not to ovalbumin. Diabetes Care 17: 970-976

38. Husby S, Oxelius VA, Teisner B, Jensenius JC, Svehag SE (1985) Humoral immunity to dietary antigens in healthy adults. Occurrence, isotype and $\mathrm{IgG}$ subclass distribution of serum antibodies to protein antigens. Int Arch Allergy Appl Immunol 77: 416-422

39. Goebel C, Kirchhoff K, Wasmuth H, Flohé S, Elliott RB, Kolb H (1999) The gut cytokine balance as a target of lead toxicity. Life Sci 64: 2207-2214 